\title{
CREATING A WINNER'S CURSE VIA JUMP BIDS
}

\author{
David Ettinger \\ Fabio Michelucci
}

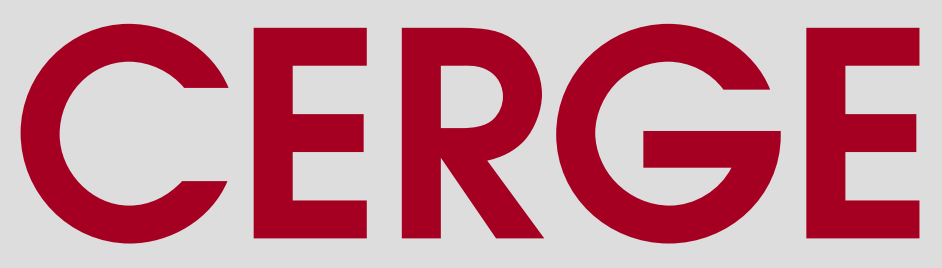




\title{
Working Paper Series 537 (ISSN 1211-3298)
}

\section{Creating a Winner's Curse via Jump Bids}

\author{
David Ettinger \\ Fabio Michelucci
}

\section{CERGE-EI}

Prague, April 2015 
ISBN 978-80-7343-342-0 (Univerzita Karlova. Centrum pro ekonomický výzkum a doktorské studium)

ISBN 978-80-7344-334-4 (Akademie věd České republiky. Národohospodářský ústav) 


\title{
Creating a Winner's Curse via Jump Bids*
}

\author{
David Ettinger ${ }^{\dagger}$ \\ PSL, Universite Paris Dauphine
}

\author{
Fabio Michelucci ${ }^{\ddagger}$ \\ CERGE-EI
}

\begin{abstract}
We show that jump bids can be used by a bidder to create a winner's curse and preserve an informational advantage that would otherwise disappear in the course of an open ascending auction. The effect of the winner's curse is to create allocative distortions and reduce the seller's expected revenue. Two novel features of equilibrium jump bids are also derived. First, the jump bid may partially reveal the value of the signal that the jump bid intends to hide. Second, the probability of calling a price might decrease with the type of the bidder who places the jump bid.
\end{abstract}

\begin{abstract}
Abstrakt
Ukazujeme, že skokové nabídky mohou být použity dražitelem k vytvořen vítězova prokletí a zachování informační výhody, která by jinak zanikla v průběhu otevřené vzestupné aukce. Efektem vítězova prokletí je vytvoření alokačních distorzí a snžení očekávaného přjmu pro prodejce. Dále jsou odvozeny dvě nově vlastnosti rovnovážných skokových nabídek. Zaprvé skoková nabídka může ăástečně odhalit hodnotu signálu, který má skoková nabídka skrýt. Zadruhé pravděpodobnost dorovnán ceny může klesat s typem dražitele, který zadává skokovou nabídku.

JEL Classification Numbers: D44, D82. Keywords: auctions, efficiency, jump bids, winner's curse.

\footnotetext{
${ }^{*}$ We would like to thank Krešimir Žigić for helpful comments on the paper, and Deborah Nováková for English language editing. All errors remaining in this text are the responsibility of the authors.

${ }^{\dagger}$ PSL, Université Paris Dauphine, LEDa, CEREMADE. Place du Maréchal de Lattre de Tassigny 75775 Paris Cedex 16 France, david.ettinger.fr@gmail.com.

${ }^{\ddagger}$ Fabio Michelucci, CERGE-EI, P.O. Box 882 Politickych veznu 711121 Praha 1 Czech Republic. Email: fabio.michelucci@cerge-ei.cz. CERGE-EI, a joint workplace of Charles University and the Economics Institute of the Academy of Sciences of the Czech Republic, Politickych veznu 7, 11121 Prague, Czech Republic.
} 


\section{Introduction}

Jump bidding refers to the practice of calling a price strictly higher than the current highest standing bid in an open ascending auction. The use of jump bids is widespread (and extensively documented) both in auctions ${ }^{1}$ and in other markets not explicitly regulated by auction rules such as corporate takeovers. ${ }^{2}$

Despite the prominence of jump bids, few theoretical contributions are devoted to their analysis. The existing work on the topic is typically based on signaling models, see Fishman (1988) and Avery (1998) for the pioneering contributions of this approach, in which a bidder places a costly jump bid to reveal that he has a favorable type. Recently, an alternative explanation based on the idea that a jump bid can hide/manipulate information has been introduced by Ettinger and Michelucci (2015). In that paper we consider a setting where one bidder (the one who has an incentive to jump bid) might benefit less than other bidders from the aggregation of information that is revealed by observing at what price another bidder leaves the auction. In particular, the identity of the opponent with the highest ex-post valuation that this bidder faces depends on such information. This latter condition is crucial to build the argument we use in Ettinger and Michelucci (2015). Without jump bids, the information that determines the identity of the opponent with the highest ex-post valuation is aggregated and therefore the bidder who is considering the jump bid pays, conditional on winning, the upper envelope of his opponents ex post valuations. Thus, the expected price he pays conditional on winning is given by his expectation of the highest value of his opponents. The jump bid, by concealing the information that determines the highest ex post valuations of the opponents, affects the expected price paid conditional on winning, which becomes the maximum of the price called and the expected valuations of the opponents, given the more coarse information they can aggregate because of the jump bid. In Ettinger and Michelucci (2015) we show that a bidder can decrease the expected price he pays by using jump bids.

In this paper, we also follow the hiding/manipulating information motive for jump bidding. However, we suggest a different reason why a bidder might want to conceal information

\footnotetext{
${ }^{1}$ See, for instance, Cramton (1997), Plott and Salmon (2004), Börgers and Dustmann (2005), Mark, Salmon, and Zillante (2007)) for FCC auctions; and Easley and Tenorio (2004), He and Popkowski Leszczyc (2013), and Grether, Porter, and Shum (2015) for online auctions.

${ }^{2}$ See Burkart and Panunzi (2008) for a review of takeovers in finance (there a jump bid determines the so called takeover premium).
} 
from other competitors: to impose a winner's curse that would otherwise not arise without the use of jump bids. We have in mind situations in which a subset of the bidders have better information about some common value elements of the object on sale (perhaps because they are insiders/incumbents) than others (entrants), and where this informational asymmetry might disappear (or narrow) because of the information that can be aggregated in the open ascending auction. A winner's curse arises in this type of environment if the bidder that is less well informed about the realization of the common value component does not take into account that the exit of the more informed bidder might imply him winning at a price higher than his value. In equilibrium, the winner's curse is avoided because the less informed bidder correctly takes into account the event of being allocated the object. In some cases, this implies that the equilibrium bid that is conditional on the equilibrium allocation is lower than the expected value that is not conditional on the same event. The observation above suggests that in an open ascending auction a bidder might reduce the aggressiveness of an opponent, and therefore the expected price paid when winning, by creating the condition for a winner's curse. In this paper we formalize this intuition and show that a winner's curse may arise endogenously as a consequence of the strategic choice of a bidder to dampen the bids of some of his opponents.

Because the reason to conceal information is different from the ones in our previous work, the argument used here to show the existence of a jump bid equilibrium does not rely on the envelope argument previously sketched when commenting on Ettinger and Michelucci (2015), but solely on the objective of imposing a winner's curse. In fact, in our setting, the identity of the opponent with the highest ex-post value is known from the start by the bidder who may jump bid, which means that the arguments used in Ettinger and Michelucci (2015) cannot be applied. Furthermore, unlike in our previous work, the open ascending auction (when jump bids are not allowed) implements the efficient allocation so that jump bidding cannot improve efficiency. The effect of a jump bid on efficiency in our framework is either negative or neutral. Another difference in terms of set-up is that here we allow the bidder that has an incentive to jump bid to know the information that would be revealed without the jump bid. In general, this could led to an unravelling process that might prevent the existence of jump bids in equilibrium. The unraveling process is avoided precisely because of the winner's curse that is created. 
Finally, in terms of equilibrium outcome, the current setting also adds two interesting new features of equilibrium jump bids. First, the jump bid may partially reveal the value of the signal that it intends to hide. Second, the probability to call a price might decrease with the type of the bidder who places the jump bid. This can be seen as a counterpart of the non monotonicity of jump bids for signaling motives shown by Hörner and Sahuguet (2007) (although for rather different strategic reasons). The rest of the paper is organized as follows. Section 2 introduces the auction rules. Section 3.1 presents the simplest set-up where we can show that jump bids can arise to create a winner's curse. Section 3.2 presents two variations of the basic set-up that introduce important additional strategic elements into the analysis. Section 4 concludes.

\section{Auction Rules}

We compare two variants of the English auction: the well known standard clock auction format starting from price 0 (see, for instance, Krishna (2010)) and the dynamic clock auction in which bidders are allowed to call a price strictly higher than 0 at the beginning of the auction (see Avery (1998)).

There are two stages in the dynamic clock auction. In the first stage, bidders privately communicate to the auctioneer the jump bid that they want to place. The second stage works as a standard clock auction format. If no price has been called, the auction starts at price 0 . If at least one strictly positive price has been called in the first stage, the auctioneer communicates the identity of the bidders who have called the highest price, $p$, and the remaining bidders independently communicate to the auctioneer whether they want to be active when the clock auction starts at price $p$ (any bidder who has called a strictly positive price in the first stage commits to be active at that price at the start of the second stage). Before the ascending auction starts from price $p$, the set of active bidders is made known publicly by the auctioneer. 


\section{Setting}

We consider the following framework with three bidders. ${ }^{3}$ Bidders' valuations are:

- $v_{1}=s$.

- $v_{i}=s+t_{i}, i=2,3$.

Bidders' valuations therefore depend on the value of $s ; s$ is privately observed by Bidder 1 and Bidder 2. Bidder 2 and Bidder 3's valuations are ex-ante symmetric. However, Bidder 3 has an informational disadvantage, he does not know the realization of $s$. He only knows that $s$ is distributed according to a uniform distribution on the interval $[0,1]$. The valuations above also assume that Bidder 2 and Bidder 3 have extra motivations for buying the good, so that Bidder 1 never has the highest valuation for the good. The fact that Bidder 1 never has the highest valuation for the good is not needed, but it helps to clarify the motive for concealing information. In fact, it implies that the opponent with the highest value for Bidder 2 is always Bidder 3, which does not allow use of the envelope argument provided in Ettinger and Michelucci (2015).

For $i=2,3$, Bidder $i$ receives private information $t_{i} . t_{2}$ and $t_{3}$ are i.i.d, independent of the value of $s$, and their realizations are equally likely.

In the next subsection we start analyzing the case where $t_{i}$ can be equal either to $t_{l}$, or $t_{h}$, with $1 \leq t_{l}<t_{h}$. This case is the simplest where we can show the existence of a jump bid equilibrium motivated by the objective to impose a winner's curse on some opponent, but its simplicity removes some interesting strategic elements that are more generally present. In particular, the main feature of the equilibrium we present is that the bidder who has an incentive to jump bid (Bidder 2) places a jump bid always and for the same value, regardless of the realization of his private type, $t_{2}$, or of the common value signal, $s$.

Thus, to enrich our analysis, in the following subsection, we analyze two variations that aim to introduce more strategic complexity. The first captures the extra features that are present when allowing for more than two types by adding an "intermediate type", $t_{m}$. In particular, it allows us to show that the probability to call a price might decrease with the type of the bidder who places the jump bid, which also means that Bidder 2 does not always

\footnotetext{
${ }^{3}$ Note that three is the minimum number of bidders that is needed to have a jump bid for the motive we propose in this paper.
} 
place a jump bid. The second one relaxes the condition $t_{l} \geq 1 . t_{l} \geq 1$ makes the analysis simpler because the equilibrium jump bid can be independent of $s$. Thus, considering $t_{l}<1$ allows us to show that the level of the jump bid may partially reveal the value of the signal that the jump bid intends to hide.

In all our set-ups, we consider a discrete rather than a continuous type space for the $t_{i}$ 's to simplify the exposition and computations. Finally, we restrict our attention to equilibria with non weakly dominated strategies and, when we refer to equilibrium below, the solution concept is Perfect Bayesian Equilibrium (PBE).

\subsection{The Baseline Set-up}

We first start with the case $t_{i} \in\left\{t_{l}, t_{h}\right\}$, with $1 \leq t_{l}<t_{h}<t_{l}+1{ }^{4}$ The equilibrium analysis of the game where jump bids are not allowed is standard, and the equilibrium actions are presented below.

Result 1. In any equilibrium of the clock auction without jump bids, Bidder 1 leaves the auction at a price equal to $s$; Bidder 2 leaves the auction at a price equal to $s+t_{2}$; and Bidder 3 leaves the auction at a price equal to $q+t_{3}, q$ being the price at which Bidder 1 leaves the auction. Bidder 2 (resp. Bidder 3)obtains the good, if $t_{2} \geq t_{3}$ (resp: $t_{3} \geq t_{2}$ ), at a price equal to $s+t_{3}$ (resp: $\left.s+t_{2}\right)$ and makes a profit equal to $t_{2}-t_{3}\left(\right.$ resp: $\left.t_{3}-t_{2}\right)$. If $t_{2}=t_{3}$, Bidder 2 and Bidder 3 tie and the tie is resolved by a random draw that assigns the good to the two bidders with equal probability.

The auction is efficient and the expected revenue is $1 / 2+\left(3 t_{l}+t_{h}\right) / 4$.

Bidder 1 and Bidder 2 have a unique weakly dominant strategy; they stay active up to their respective valuations for the good. By observing Bidder 1's behavior, Bidder 3 can perfectly infer his valuation for the good and stay active up to $v_{3}$. Hence, the simplicity of the equilibrium prediction. The auction process allows the piece of information that is not known by all the bidders at the beginning of the auction to be perfectly revealed.

We show that the opportunity to call a price may dramatically modify the equilibrium analysis and the outcome of the auction in the game where jump bids are allowed. The

\footnotetext{
${ }^{4}$ The condition $t_{h}<t_{l}+1$ is not necessary for the existence of the equilibria we mention but we added it because it induces that Bidder 3 cannot infer the value of $s$ by observing the value of $v_{2}$ for any value of $v_{2}$. There exist values of $v_{2}$ that can be obtained either with $t_{2}=t_{l}$ and high values of $s$ or with $t_{2}=t_{h}$ and low values of $s$.
} 
following result introduces the actions taken along the equilibrium path in the equilibrium we consider (equilibrium strategies are specified in full in the appendix).

Result 2. There exists an equilibrium of the dynamic clock auction in which:

- Bidder 2 always calls price $p=1$ and then stays active up to $s+t_{2}$.

- Bidder 1 immediately leaves the auction after the jump bid by Bidder 2 at price $p=1$.

- Bidder 3 never calls a price. After Bidder 2 calls price $p=1$, Bidder 3 stays active up to $t_{l}$, if $t_{3}=t_{l}$, and up to $1+t_{h}$, if $t_{3}=t_{h}$.

Proof. In the Appendix.

Bidder 1's strategy is easy to understand. In any case, the good is worth less than 1 for him so that he prefers staying out after the jump bid to price $p=1$. The strategies of Bidder 2 and Bidder 3 in this equilibrium build on the winner's curse issue. Bidder 2 knows the value of $s$ and Bidder 3 does not. Without jump bids, Bidder 3 can discover the value of $s$ by observing at which price Bidder 1 leaves the auction. Since bidders can place jump bids, Bidder 2 calls a price sufficiently high so that Bidder 3 cannot discover the value of $s$ by observing Bidder 1's behavior.

One may have thought that Bidder 3 would stay active up to $t_{3}+E(s \mid$ "Bidder 2 calls price $\mathrm{p}=1 ")$. If this were the case, calling price $p=1$ would not be interesting for Bidder 2 for low values of $s$. Then, Bidder 2 would not call a price for low values of $s$ and with standard unraveling arguments, we would find that Bidder 2 never calls a price.

This argument does not apply here. Since Bidder 2 is informed of the value of $s$ and he stays active up to $s+t_{2}$, for Bidder 3 , staying active up to $t_{3}+E(s \mid$ "Bidder 2 called price $\mathrm{p}=1 ")$ is not a good idea because he may become a victim of the winner's curse. This may occur if Bidder 2 leaves the auction before Bidder 3 , while $t_{3}<t_{2}$. For instance, for low values of $s, t_{l}+E\left(s \mid\right.$ "Bidder 2 called price $\mathrm{p}=1$ ") may be strictly higher than $t_{h}+s$. If he stays active up to $t_{l}+E(s \mid$ "Bidder 2 called price $\mathrm{p}=1$ "), Bidder 3 may win the auction against Bidder 2 when $t_{2}=t_{h}$ and pay $t_{2}+s>v_{3}$. In order to avoid this outcome, at the equilibrium, Bidder 3 leaves the auction earlier than $t_{l}+E(s \mid$ "Bidder 2 called price $\mathrm{p}=1$ ").

If $t_{3}=t_{h}$, the winner's curse is not an issue for Bidder 3 , since $t_{3}<t_{2}$ is not possible. Therefore, when $t_{3}=t_{h}$, Bidder 3 stays active up to his highest possible valuation, $1+t_{h}$, since he does not fear becoming a victim of the winner's curse. 
If $t_{3}=t_{l}$, the winner's curse is an issue for Bidder 3 . He knows that $t_{3} \leq t_{2}$ and that Bidder 2 will leave the auction at a price equal to $s+t_{2}$ higher or equal to his valuation for the good so that he cannot derive any profit by staying active in the auction. Then, in order to avoid buying the good for a price higher than his valuation for it, he leaves the auction at a price equal to his lowest possible valuation for the good: $t_{l}$.

Now, let us consider Bidder 2's motives. If $t_{2}=t_{l}$, it is clear that calling price $p=1$ is profitable: if he does not call a price, he obtains no profit; while if he calls it, he obtains a strictly positive profit when $t_{3}=t_{l}$. If $t_{2}=t_{h}$, calling price 1 gives an extra profit $s$ when $t_{3}=t_{l}$ while, when $t_{3}=t_{h}$, Bidder 3 is indifferent between calling a price or not.

Corollary 1. In the considered equilibrium of the dynamic clock auction, the allocation is efficient and the expected seller's revenue is $1 / 4+\left(3 t_{l}+t_{h}\right) / 4$, which is strictly lower than what is obtained in any equilibrium of the standard clock auction.

The jump bid only affects the equilibrium allocation when $t_{2}=t_{3}$, but in this case whether Bidder 2 or Bidder 3 obtain the good does not affect efficiency. Bidder 2 wins when $t_{2}=t_{3}=t_{l}$ and Bidder 3 wins when $t_{2}=t_{3}=t_{h}$. The jump bid also reduces the price paid by Bidder 2 when $t_{3}=t_{l}$ by $s$, hence the expected revenue loss for the seller of $E(s) / 2=1 / 4$.

\subsection{Two Variations of the Baseline Set-up}

\subsubsection{Allowing for more than two types' realizations for $t_{i}$ 's}

We analyze the case where $t_{i} \in\left\{t_{l}, t_{m}, t_{h}\right\}$, with $1 \leq t_{l}<t_{m}<t_{h}<1+t_{l}$. The equilibrium analysis of the game where jump bids are not allowed is the same as in the previous subsection except for the obvious modifications implied by the additional type. The auction is still efficient and the expected revenue is now $1 / 2+\left(5 t_{l}+3 t_{m}+t_{h}\right) / 9$.

The equilibrium of the dynamic auction with jump bids differs from the one in the previous section because of the additional type, $t_{m}$, introduced (again, we introduce the actions played along the equilibrium path and specify strategies in the appendix).

Result 3. If $1 / 2>t_{h}-t_{m}>t_{m}-t_{l},{ }^{5}$ there exists an equilibrium of the dynamic clock

\footnotetext{
${ }^{5}$ We may obtain equilibria with the same properties with less restrictive assumptions but these assumptions ease the exposition. What is needed for the addition of $t_{m}$ to be meaningful is that $t_{h}-t_{m}>t_{m}-t_{l}$, otherwise Bidder 3 of type $t_{m}$ would display the same type of aggressive strategy as when he is type $t_{h}$ (that is being active till $t_{m}+1$ ). $t_{h}-t_{l}<1 / 2$ is imposed only to guarantee that $\tilde{s} \leq 1$, as $s \in[0,1]$ (see below for the definition of $\tilde{s})$.
} 
auction in which:

- If $t_{2} \in\left\{t_{l}, t_{m}\right\}$ (and for any value of $s$ ), or if $t_{2}=t_{h}$ and $s \geq \underline{s}$, with $\underline{s} \equiv t_{h}-t_{m}$, Bidder 2 calls price 1 and then stays active up to $s+t_{2}$. If $t_{2}=t_{h}$ and $s<\underline{s}$, Bidder 2 does not call a price and stays active up to $s+t_{2}$.

- Bidder 1 immediately leaves the auction after a jump bid by Bidder 2 at price $p=1$ and when no price is called, stays active up to $s$.

- Bidder 3 never calls a price. When Bidder 2 calls price $p=1$, Bidder 3 stays active up to $t_{l}$, if $t_{3}=t_{l}$, up to $t_{m}+\tilde{s}$ with $\tilde{s} \equiv 2 t_{h}-2 t_{m}$, if $t_{3}=t_{m}$, and up to $1+t_{h}$, if $t_{3}=t_{h}$. If no jump bid is placed, Bidder 3 leaves the auction at a price equal to $q+t_{3}$, $q$ being the price at which Bidder 1 leaves the auction.

Proof. In the Appendix.

We only point out the differences with respect to the baseline set-up. Bidder 1's strategy is unchanged. Bidder 3's strategy is unchanged if $t_{2} \in\left\{t_{l}, t_{h}\right\}$ (if $t_{2}=t_{l}$, he leaves at $t_{l}$, and always loses; if $t_{2}=t_{h}$, he leaves at $t_{h}+1$, and always wins). $t_{3}=t_{m}$ is the new case and it is also the richest one. When $t_{3}=t_{m}$, Bidder 3 fears the winner's curse (in case $t_{2}=t_{h}$ ) but, if he leaves the auction too early, he may miss an opportunity to derive a strictly positive profit (in case $t_{2}=t_{l}$ ). Bidder 3 can safely stay active up to $t_{h}$ since if Bidder 2 leaves the auction for a price lower than $t_{h}$, it must be the case that $t_{2} \leq t_{m}$. Further, if $s<\tilde{s}$ and $t_{2}=t_{h}$, Bidder 2 does not call a price. Therefore, Bidder 3 knows that after a jump bid, Bidder 2 cannot have a high type if he leaves at a price below $t_{h}+\tilde{s}$. Therefore, he can stay active up to $t_{h}+\tilde{s}$ without fearing the winner's curse. Now, after a jump bid, if Bidder 2 leaves at a price higher than $t_{h}+\tilde{s}$, the probability that $t_{2}=t_{h}$ is at least as high as the probability that $t_{2}=t_{l}$. Further, the loss that Bidder 3 with type $t_{m}$ makes if he wins and $t_{2}=t_{h}$ (i.e. $\left.t_{h}-t_{m}\right)$ is larger than his profit if he wins and $t_{2}=t_{l}$ (i.e. $t_{m}-t_{l}$ ). Therefore, Bidder 3 with $t_{3}=t_{m}$ prefers to leave the auction at price $t_{h}+\tilde{s}$.

Let us consider how Bidder 2's strategy is affected. If $t_{2}=t_{l}$, it is again clear that calling price $p=1$ is profitable. If $t_{2}=t_{m}$, without jump bids, Bidder 2 obtains an expected profit of $\left(t_{m}-t_{l}\right) / 3$, while with a jump bid he obtains $\left(t_{m}-t_{l}+s\right) / 3+\max \left(0, s-2 t_{h}+2 t_{m}\right) / 3$. Thus, calling price 1 is profitable. If $t_{2}=t_{h}$, there is a trade off. Calling price 1 gives an 
extra profit $s$, when $t_{3}=t_{l}$; while, when $t_{3}=t_{m}$, calling price $p=1$ is counterproductive for low values of $s$ because Bidder 3 stays active up to $2 t_{h}-t_{m}$, which is higher than $t_{m}+s$ when $s<2 t_{h}-2 t_{m}=\tilde{s}$. Hence, there exists a level of $s, \underline{s}$, for which Bidder 2 with type $t_{h}$ is indifferent between calling a price or not. For $s<\underline{s}$, no price is called, and for $s \geq \underline{s}$, price $p=1$ is called.

Corollary 2. The probability of observing a jump bid by Bidder 2 is strictly lower when $t_{2}=t_{h}$, than for $t_{2}=t_{l}$ and $t_{2}=t_{m}$.

The result stated in the corollary above might appear surprising. Typically in signaling games higher types can mimic lower types, which here would imply that if a lower type finds it profitable to place a jump bid, so should a higher type. This argument does not apply in our case despite the fact that, conditional on having called price $p=1$, Bidder 2 would prefer Bidder 3 to believe that $t_{2}$ is high. Similarly, Bidder 2 would prefer Bidder 3 to believe that the expected value of $s$ is lower after a jump bid, which again is not the case. The explanation is that the jump bid reveals some information about $s$ that Bidder 3 can use to bid more aggressively (when $t_{3}=t_{m}$ ), and that Bidder 2 is more affected by this change in behavior caused by the jump bid when $t_{2}=t_{h}$ and $s<\underline{s}$. To see why, recall that there is a trade-off of costs and benefits between placing a jump bid or not when $t_{2}=t_{h}$, while there is no such trade off (there are only benefits from jump bidding) when $t_{2}=t_{l}$ or $t_{2}=t_{m}$ because those types of Bidder 2 can never profitably win against a Bidder 3 of type $t_{3}=m$ if jump bids are not used.

Corollary 3. In the considered equilibrium of the dynamic clock auction, the allocation may be inefficient, if $2 t_{h}-t_{m}<1+t_{l}$, and the expected revenue is strictly lower than in any equilibrium of the standard clock auction.

\section{Proof.}

Inefficiency: Consider the case $2 t_{h}-t_{m}<1+t_{l}$. If $\left(t_{2}, t_{3}\right)=\left(t_{l}, t_{m}\right)$, Bidder 2 calls price $p=1$ and stays active up to $s+t_{l}$, Bidder 3 leaves the auction at price $t_{m}+2 t_{h}-2 t_{m}=2 t_{h}-t_{m}$. Since $2 t_{h}-t_{m}<1+t_{l}$, there exist values of $s$ sufficiently close to 1 such that $2 t_{h}-t_{m}<s+t_{l}$. For these values of $s$, Bidder 2 wins the auction although Bidder 3 has a higher valuation for the good. 
Expected revenue: The only case in which the price may be higher in the equilibrium of the dynamic auction is when $\left(t_{2}, t_{3}\right)=\left(t_{h}, t_{m}\right)$ and $s \in\left[t_{h}-t_{m}, 2 t_{h}-2 t_{m}\right)$. Bidder 2 wins the auction and pays $2 t_{h}-t_{m}>t_{m}+s$. This represents an expected increase in revenue of $\frac{t_{h}-t_{m}}{9} \frac{t_{h}-t_{m}}{2}=\frac{\left(t_{h}-t_{m}\right)^{2}}{18}$ as compared to what is obtained in the same situation in a standard clock auction. However, when $t_{3}=t_{l}$, there is a price decrease of $s$ in a dynamic clock auction that represents an expected loss in revenue equal to $\frac{E(s)}{3}=\frac{1}{6}>\frac{\left(t_{h}-t_{m}\right)^{2}}{18}$ so that the expected revenue is strictly lower in the considered equilibrium of the dynamic clock auction than in any equilibrium of the standard clock auction.

\subsubsection{Allowing for $t_{l}<1$}

In the baseline set-up, we assumed that $t_{l}>1$. This implied that Bidder 2 had the option to call price $p=1$ hiding the values of $s$ for any values of $t_{2}$ and $s$ without any direct cost since Bidder 3 would always stay active at least up to $t_{l}>1 .^{6}$

The modification of the baseline set-up that we want to discuss is to assume that $t_{l}=\frac{1}{2}$ (note that we can also take any $t_{l} \in(0,1)$ ). The fact that jump bidding survives this modification is not trivial. In particular, the equilibrium that we proposed in section 3.1 no longer stands since when $t_{2}=t_{l}$ and $t_{l}+s<1$, Bidder 2 does not want to call price $p=1$. We argue that an equilibrium still exists in which Bidder 2 computes a jump bid that preserves the informational advantage necessary to induce a winner's curse and at the same time discloses the minimum amount of private information.

The analysis of the game where jump bids are not allowed is unchanged. Instead, the suggested equilibrium of the dynamic clock auction no longer stands, so we propose a new one.

Result 4. For $t_{l}=1 / 2$, there exists an equilibrium of the dynamic clock auction in which:

- If $s \in[0,1 / 2)$, Bidder 2 calls price $p=1 / 2$ and then stays active up to $s+t_{2}$; if $s \in[1 / 2,1]$, Bidder 2 calls price $p=1$ and then stays active up to $s+t_{2}$.

\footnotetext{
${ }^{6}$ Let us mention that an equilibrium jump bid with partitions such as the one we propose in the current subsection would also exist in the baseline set-up. However, notice that because it would reveal some information about $s$ that Bidder 2 can incorporate in his bidding, it would yield a strictly lower expected profit for Bidder 2 compared to the equilibrium we presented.
} 
- Bidder 1 immediately leaves the auction after a jump bid by Bidder 2.

- Bidder 3 never calls a price. When Bidder 2 calls price $p=1 / 2$, Bidder 3 stays active up to $t_{l}$, if $t_{3}=t_{l}$, and up to $t_{h}+1 / 2$, if $t_{3}=t_{h}$. When Bidder 2 calls price $p=1$, Bidder 3 stays active up to $t_{l}+1 / 2$, if $t_{3}=t_{l}$, and up to $t_{h}+1$, if $t_{3}=t_{h}$.

Proof. In the Appendix.

In this equilibrium, Bidder 2 always calls a price, but the price he calls depends on the value of $s$. Again, we observe that even though Bidder 2 would prefer to reveal as little information as possible regarding $s$, he does reveal some information about $s$ with his jump bid. After the jump bid, Bidder 3 knows whether $s<1 / 2$, or $s \geq 1 / 2$.

Because $t_{l}=1 / 2$, it is no longer costless for Bidder 2 to call price $p=1$, when $t_{2}=t_{l}$. However, Bidder 2 manages to partition the interval $[0,1]$ on which $s$ lies and to raise his payoff with the jump bids, since he pays $t_{l}+\frac{\mathbb{1}_{s \geq 1 / 2}}{2}$ rather than $t_{l}+s$, when $t_{3}=t_{l}$. Thus, the expected gain from jump bidding is $\frac{1}{2} E\left(s-\frac{\mathbb{1}_{s \geq 1 / 2}}{2}\right)=\frac{1}{8}$.

Intuitively, the more coarsly the interval $[0,1]$ is partitioned, the less information is communicated to Bidder 3, which is good for the purpose of imposing a winner's curse. However, there is some restriction on how the interval $[0,1]$ can be partitioned because the size of the elements of the partition cannot be larger than $t_{l}$ (note that this is the size of the partitions in the equilibrium provided). As a matter of fact, it cannot be part of an equilibrium for Bidder 2 to call a price strictly higher than $v_{2}$. Therefore, if $t_{2}=t_{l}$, Bidder 2 does not call more than $1 / 2+s$. Now, calling less than $s$ is useless since with such a low jump bid, Bidder 1 stays active after the jump bid and $s$ is revealed during the auction process in any case. Then, at the equilibrium, Bidder 2 with a type $t_{l}$ only calls a price in the interval $\left[s, s+t_{l}\right]$. This explains why the size of the elements of the partition cannot exceed $t_{l}$.

We chose to illustrate the $t_{l}<1$ case considering $t_{l}=1 / 2$. However, we could obviously build an equilibrium with several jump bids partitioning the interval $[0,1]$ for any value of $t_{l} \in(0,1)$. The size of the elements of the partition will never exceed $t_{l}$. 


\section{Conclusion}

The use of jump bidding strategies is widespread in many markets ranging from standard auctions to takeover contests. This paper suggests a novel strategic use of jump bidding; creating a winner's curse in an environment where it would not arise otherwise.

The bidder calling the price exploits the fear of suffering from a winner's curse that his jump bid creates for another bidder to decrease the price he pays. This reduces efficiency and expected revenue for the seller. For sensible values of the parameters of the model, we also observe that the bidder calling a price is less likely to do so when he has a more favorable private type. The price he calls may also depend on his private information. In that case, the jump bid partially reveals the information it intends to hide. 


\section{Appendix}

\subsection{Proof of Result 2}

Consider the following strategies:

- Bidder 1. Never calls a price, stays active up to $s$, and leaves the auction if a price higher than $s$ is called.

- Bidder 2. Always calls price $p=1$ and stays active up to $s+t_{2}$ afterwards. If a bidder calls a price higher than $p=1$, stays active up to $s+t_{2}$.

- Bidder 3. Never calls a price. If no price is called, leaves the auction at a price equal to $q+t_{3}, q$ being the price at which Bidder 1 leaves the auction if it is in the interval $[0,1]$. If Bidder 1 does not leave the auction at a price lower than 1, Bidder 3 stays active up to $1+t_{3}$.

If a price $p$ is called in the first stage:

(a) If Bidder 2 calls a price $p$ strictly lower than 1, Bidder 3 stays active after the jump bid. Then, if Bidder 1 stays active after the jump bid, Bidder 3 behaves as in the case without jump bid. If Bidder 1 does not stay active after the jump bid, Bidder 3 stays active up to $t_{3}+p$. If Bidder 2 calls a price $p$ strictly higher than 1, Bidder 3 stays active after the jump bid up to $1+t_{3}$. If Bidder 2 calls a price $p=1$, Bidder 3 stays active after the jump bid. Then, if Bidder 3 has type $t_{3}=t_{l}$, he stays active up to $t_{l}$; else, he stays active up to $t_{h}+1$.

(b) If Bidder 1 calls a price $p<1$, Bidder 3 stays active and then leaves the auction at a price equal to $q+t_{3}, q$ being defined as before. If Bidder 1 does not leave the auction at a price lower than 1 , Bidder 3 stays active up to $1+t_{3}$. If Bidder 1 calls a price $p \geq 1$, Bidder 3 stays active up to $1+t_{3}$.

If bidders choose these strategies, their behaviors coincide with what we describe in result 2 . Now we need to show that these strategies constitute an equilibrium.

Bidder 1: Staying active beyond (or calling a price higher than) his valuation is weakly dominated. Further, considering Bidder 2 and Bidder 3's strategies, Bidder 1 cannot make a profitable deviation with a jump bid lower than his valuation. 
Bidder 2: Whether a price is called or not, in the second part of the auction, staying active up to his valuation for the good is a weakly dominant strategy. Therefore, in order to find a profitable deviation, we need to focus on the jump bidding part of the strategy, assuming that after any possible jump bid, he will stay active up to his valuation for the good.

If Bidder 2 does not call a price or calls a price lower than $s$, Bidder 3 discovers the value of $s$ by observing the price at which Bidder 1 leaves the auction and Bidder 3 stays active up to $s+t_{3}$. We take this into account to evaluate Bidder's 3 equilibrium strategy, and consider separately the different possible values of $t_{2}$.

$t_{2}=t_{l}$. If Bidder 2 calls price $p=1$, he obtains an expected payoff equal to $s / 2$. If he does not call a price or calls a price strictly lower than $s$, he obtains 0 . If he calls a price $p \in[s, 1)$, he cannot obtain more than what he obtains when he calls price $p=1$. If he calls a price strictly higher than 1 , he obtains 0 . Hence, there is no profitable deviation when $t_{2}=t_{l}$.

$t_{2}=t_{h}$. If Bidder 2 calls price $p=1$, he obtains an expected payoff equal to $\left(t_{h}-t_{l}+s\right) / 2$. If he does not call a price or calls a price strictly lower than $s$, he obtains $\left(t_{h}-t_{l}\right) / 2$. If he calls a price $p \in[s, 1)$, he cannot obtain more than what he obtains when he calls price $p=1$. If he calls a price strictly higher than 1 , he obtains $\max \left(0, t_{h}+s-t_{l}-1\right) / 2$. Hence, there is no profitable deviation when $t_{2}=t_{h}$.

Bidder 3: We first consider deviations that do not involve calling a price and consider separately the different possible values of $t_{3}$.

$t_{3}=t_{l}$. If Bidder 2 calls price $p=1$ (or any price greater or equal than $s$ ), he never leaves the auction for a price lower than $s+t_{l}$. Therefore, conditional on winning the auction, Bidder 3 can only make a negative profit. Leaving the auction at price $t_{l}$,j Bidder 3 avoids winning and picks a strategy that is not dominated. If no price is called (or a price lower than $s$ is called), Bidder 3 discovers the value of $s$ by observing at which price Bidder 1 leaves the auction. Then, staying active up to $q+t_{h}$ is a weakly dominant strategy.

$t_{3}=t_{h}$. If Bidder 2 calls price $p=1$ (or any price greater or equal than $s$ ), he never leaves the auction at a price strictly higher than $s+t_{h}$, which means that Bidder 3 always wins and never makes a loss when winning. Thus, the proposed equilibrium strategy is not dominated. If no price is called (or a price lower than $s$ is called), Bidder 3 discovers the value of $s$ by observing at which price Bidder 1 leaves the auction. Then, staying active up to $q+t_{h}$ is a 
weakly dominant strategy.

Now, let us consider deviations that include jump bids.

Suppose that Bidder 3 calls a price lower than 1 . This jump bid does not qualify as the highest jump bid in the first stage, so it yields the same outcome as not calling a price at all. Suppose that Bidder 3 calls a price $p \in\left[1, t_{l}\right]$. After the jump bid, Bidder 2 stays active up to $v_{2}$. Bidder 3's information is the same as in the case when Bidder 2 is the bidder placing the highest bid in the first stage. Thus, calling a price $p \in\left[1, t_{l}\right]$ cannot be part of a profitable deviation. We can show with the same type of arguments that calling a price $p>t_{l}$ cannot be part of a profitable deviation either (Bidder 3 does not obtain more information when $t_{2}+s \geq p$ and if $t_{2}+s \geq p$, the jump bid makes him lose money).

Q.E.D.

\subsection{Proof of Result 3}

Consider the following strategies:

- Bidder 1. Never calls a price, stays active up to $s$ and leaves the auction if a price higher than $s$ is called.

- Bidder 2. If $t_{2}=t_{l}, t_{m}$ and if $t_{2}=t_{h}$ and $s>t_{h}-t_{m}$, calls price $p=1$ and stays active up to $s+t_{2}$ afterwards. If $t_{2}=t_{h}$ and $s<\underline{s}$, does not call a price and stays active up to $t_{h}+s$. If a bidder calls a price higher than 1 , stays active up to $s+t_{2}$.

- Bidder 3. Never calls a price. If no price is called, Bidder 3 leaves the auction at a price equal to $q+t_{3}, q$ being the price at which Bidder 1 leaves the auction if it in the interval $[0,1]$. If Bidder 1 does not leave the auction at price lower than 1 , Bidder 3 stays active up to $1+t_{3}$.

If a price $p$ is called in the first stage:

(a) If Bidder 2 calls a price $p$ strictly lower than 1 , Bidder 3 stays active after the jump bid. Then, if Bidder 1 stays active after the jump bid, Bidder 3 behaves as in the case without jump bid. If Bidder 1 does not stay active after the jump bid, Bidder 3 stays active up to $t_{3}+p$. If Bidder 2 calls a price $p$ strictly higher than 1, Bidder 3 stays active after the jump bid up to $1+t_{3}$. If Bidder 2 calls a price 
$p=1$, Bidder 3 stays active after the jump bid. Then, if Bidder 3's type is $t_{l}$, he stays active up to $t_{l}$; if $t_{3}=t_{m}$, he stays active up to $2 t_{h}-t_{m}$; and if $t_{3}=t_{h}$, he stays active up to $t_{h}+1$.

(b) If Bidder 1 calls a price $p<1$, Bidder 3 stays active and then leaves the auction at a price equal to $q+t_{3}, q$ being defined as before. If Bidder 1 does not leave the auction at a price lower than 1 , Bidder 3 stays active up to $1+t_{3}$. If Bidder 1 calls a price $p \geq 1$, Bidder 3 stays active up to $1+t_{3}$.

If bidders choose these strategies, their behaviors coincide with what we describe in result 3 . Now we need to show that these strategies constitute an equilibrium.

Bidder 1: Analogous argument as for the proof of Result 2.

Bidder 2: We stress only the parts that differ from the proof of Result 2.

$t_{2}=t_{l}$. Same argument as in the proof of Result 2 except that now the expected payoff in equilibrium is $s / 3+\max \left(0, t_{l}+s-2 t_{h}+t_{m}\right) / 3$.

$t_{2}=t_{m}$. If Bidder 2 calls price $p=1$, he obtains an expected payoff equal to $\left(t_{m}-t_{l}+\right.$ $s) / 3+\max \left(0,2 t_{m}+s-2 t_{h}\right) / 3$ and $\left(t_{m}-t_{l}\right) / 3$ if he does not call a price or call a price strictly lower than $s$. If he calls a price $p \in[s, 1)$, he cannot obtain more than what he obtains when he calls price 1 and if he calls a price strictly higher than 1 , he derives $\max \left(0, t_{m}+s-t_{l}-1\right) / 3$. Hence, there is no profitable deviation when $t_{2}=t_{m}$.

$t_{2}=t_{h}$. If Bidder 2 calls price $p=1$, he obtains an expected payoff equal to $t_{h}-$ $\left.t_{l}+s\right) / 3+\max \left(0, t_{m}+s-t_{h}\right) / 3$ and $\left(t_{h}-t_{l}\right) / 3+\left(t_{h}-t_{m}\right) / 3$ if he does not call a price or call a price strictly lower than $s$. If he calls a price $p \in[s, 1)$, he cannot obtain more than what he obtains when he calls price 1 and if he calls a price strictly higher than 1 , he derives $\max \left(0, t_{h}+s-t_{l}-1\right) / 3+\max \left(0, t_{h}+s-t_{m}-1\right) / 3$. Therefore, Bidder 2's best choice are either calling price 1 or not calling a price. The first alternative gives him $\left(t_{h}-t_{l}+s\right) / 3+\max \left(0, t_{m}+s-t_{h}\right) / 3$ and the second one $\left(t_{h}-t_{l}\right) / 3+\left(t_{h}-t_{m}\right) / 3$. When $s \geq \underline{s}$, the first alternative gives him a higher payoff and calling price $p=1$ is a better response and when $s<\underline{s}$, the second alternative gives him a higher payoff and not calling any price is a better response. Hence, there is no profitable deviation when $t_{2}=t_{h}$.

Bidder 3: We first consider deviations that do not involve calling a price and consider separately the different possible values of $t_{3}$. 
$t_{3}=t_{l}$. Same argument as in the proof of Result 2.

$t_{3}=t_{m}$. If Bidder 2 calls price $p=1$ and leaves the auction at a price below $t_{h}+\tilde{s}$, the probability that $t_{2}=t_{h}$ is zero. Therefore, $v_{2} \leq v_{3}$ and since Bidder 2 leaves the auction at a price equal to $v_{2}$, staying active up to $t_{h}+\tilde{s}$ is not costly and it may be profitable. Therefore, Bidder 3 cannot profitably deviate leaving the auction at a price lower than $t_{h}+\tilde{s}$. Now, suppose that Bidder 3 considers leaving the auction at a price strictly higher than $t_{h}+\tilde{s}$. Since the expected value of $v_{3}$ conditional on Bidder 2's leaving the auction at a price $p$ strictly higher than $t_{h}+\tilde{s}$ is strictly lower than $p$ (since $t_{h}-t_{m}>t_{m}-t_{l}$ ), such a deviation cannot be profitable either. If no price is called, Bidder 3 discovers the value of $s$ by observing at which price Bidder 1 leaves the auction. Then, staying active up to $q+t_{m}$ is a weakly dominant strategy.

$t_{3}=t_{h}$. Same argument as in the proof of Result 2.

Now, let us consider deviations that include jump bids.

Since Bidder 2 always leaves the auction at a price equal to $s+t_{2}$, Bidder 3 cannot make any profitable deviation even if it includes a jump bid when $t_{3}=t_{l}$ (he cannot derive any profit) and when $t_{3}=t_{h}$ (he cannot win the auction at a price strictly lower than $t_{2}+s$ ) so that we only need to consider $t_{3}=t_{m}$.

Suppose that Bidder 3 calls a price lower than 1 . This jump bid could only affect the auction when $t_{2}=t_{h}$ and $s<\tilde{s}$. However, in that case, Bidder 2 stays active up to $t_{h}+s$ after the jump bid and Bidder 3 cannot obtain any strictly positive profit.

Suppose that Bidder 3 calls a price $p \in\left(1, t_{l}\right]$. After the jump bid, Bidder 2 stays active up to $v_{2}$. Bidder 3's information is the same as in the case when Bidder 2 calls price $p=1$ except that he cannot distinguish the cases when $t_{2}=t_{h}$ and $s<\tilde{s}$. Therefore, Bidder 3 is better off leaving the auction at a price equal $t_{h}$ rather than staying active up to $t_{h}+\tilde{s}$. Hence, calling price $p$ lowers his expected payoff by $\min \left(t_{l}+1-t_{h}, \tilde{s}\right)\left(t_{m}-t_{l}\right)$. Calling a price $p \in\left(1, t_{l}\right]$ cannot be part of a profitable deviation.

The same type of arguments applies for a jump bid $p>t_{l}$ so that it cannot be part of a profitable deviation either.

Q.E.D. 


\subsection{Proof of Result 4}

Consider the following strategies:

- Bidder 1. Never calls a price, stays active up to $s$ and leaves the auction if a price higher than $s$ is called.

- Bidder 2. If $s \in[0,1 / 2)$ calls price $p=1 / 2$ and stays active up to $s+t_{2}$ afterwards. If $s \in[1 / 2,1]$ calls price 1 and stays active up to $s+t_{2}$ afterwards. If a bidder calls a price higher than the price called by Bidder 2, stays active up to $s+t_{2}$.

- Bidder 3. Never calls a price. If no price is called, Bidder 3 leaves the auction at a price equal to $q+t_{3}, q$ being the price at which Bidder 1 leaves the auction if it is in the interval $[0,1]$. If Bidder 1 does not leave the auction at a price lower than 1 , Bidder 3 stays active up to $1+t_{3}$.

If a price $p$ is called in the first stage:

(a) If Bidder 2 calls a price $p$ strictly lower than 1 with $p \neq 1 / 2$, Bidder 3 stays active after the jump bid. Then, if Bidder 1 stays active after the jump bid, Bidder 3 behaves as in the case without jump bid. If Bidder 1 does not stay active after the jump bid, Bidder 3 stays active up to $t_{3}+p$. If Bidder 2 calls a price $1 / 2$, Bidder 3 stays active after the jump bid. Then, if Bidder 1 stays active after the jump bid, Bidder 3 behaves as in the case without jump bid. If Bidder 1 does not stay active after the jump bid, Bidder 3 stays active up to $t_{l}+1 / 2$ and if $t_{3}=t_{h}$, he stays active up to $t_{h}+1$. If Bidder 2 calls a price $p=1$, Bidder 3 stays active after the jump bid. If Bidder 3 has type $t_{3}=t_{l}$, he stays active up to $t_{l}+1 / 2$; if $t_{3}=t_{h}$, he stays active up to $t_{h}+1$. If Bidder 2 calls a price $p=1$, Bidder 3 stays active after the jump bid. If Bidder 3 has type $t_{3}=t_{l}$, he stays active up to $t_{l}+1 / 2$; if $t_{3}=t_{h}$, he stays active up to $t_{h}+1$. If Bidder 2 calls a price $p$ strictly higher than 1, Bidder 3 stays active after the jump up to $1+t_{3}$.

(b) If Bidder 1 calls a price $p<1$, Bidder 3 stays active and then leaves the auction at a price equal to $q+t_{3}, q$ being defined as before. If Bidder 1 does not leave the auction at a price lower than 1 , Bidder 3 stays active up to $1+t_{3}$. If Bidder 1 calls a price $p \geq 1$, Bidder 3 stays active up to $1+t_{3}$. 
If bidders choose these strategies, their behaviors coincide with what we describe in result 4 . Now we need to show that these strategies constitute an equilibrium.

Bidder 1: Analogous arguments as in the proof of Result 2.

Bidder 2: We stress only the parts that differ from the proof in Result 2.

(a) If $s \geq 1 / 2$

$t_{2}=t_{l}$. If Bidder 2 calls price $p=1$, he obtains a payoff equal to $(s-1 / 2) / 2$. If he does not call a price or call a price strictly lower than $s$, he obtains 0 . If he calls a price $p \in[s, 1)$, he does not obtain more than what he obtains when he calls price $p=1$. If he calls a price strictly higher than 1 , he derives obtains 0 . Hence, there is no profitable deviation when $t_{2}=t_{l}$.

$t_{2}=t_{h}$. If Bidder 2 calls price $p=1$, he obtains a payoff equal to $\left(t_{h}-t_{l}+(s-1 / 2)\right) / 2$. If he does not call a price or call a price strictly lower than $s$, he obtains $\left(t_{h}-t_{l}\right) / 2$. If he calls a price $p \in[s, 1)$, he does not obtain more than what he obtains when he calls price $p=1$. If he calls a price strictly higher than 1 , he derives $\max \left(0, t_{h}+s-t_{l}-1\right) / 2$. Hence, there is no profitable deviation when $t_{2}=t_{h}$.

(b) If $s<1 / 2$

$t_{2}=t_{l}$. If Bidder 2 calls price $p=1 / 2$, he obtains a payoff equal to $s / 2$. If he does not call a price or call a price strictly lower than $s$, he obtains 0 . If he calls a price $p \in[s, 1]$, he does not obtain more than what he obtains when he calls price $p=1 / 2$. If he calls a price strictly higher than 1 , he obtains 0 . Hence, there is no profitable deviation when $t_{2}=t_{l}$.

$t_{2}=t_{h}$. If Bidder 2 calls price $p=1 / 2$, he obtains a payoff equal to $\left.\left(t_{h}-t_{l}+s\right)\right) / 2$. If he does not call a price or call a price strictly lower than $s$, he obtains $\left(t_{h}-t_{l}\right) / 2$. If he calls a price $p \in[s, 1]$, he does not obtain more than what he obtains when he calls price $p=1 / 2$. if he calls a price strictly higher than 1 , he derives $\max \left(0, t_{h}+s-t_{l}-1\right) / 2$. Hence, there is no profitable deviation when $t_{2}=t_{h}$.

Bidder 3: $t_{3}=t_{l}$. Same arguments as in the proof of Result 2. $t_{3}=t_{h}$. Same argument as in Result 2.

Q.E.D. 


\section{References}

Avery, C. (1998): "Strategic Jump Bidding in English Auctions," The Review of Economic Studies, 65, 185-210.

Börgers, T., and C. Dustmann (2005): "Strange Bids: Bidding Behaviour in the United Kingdom's Third Generation Spectrum Auction," The Economic Journal, 115(505), 551578.

Burkart, M., and F. PAnunzi (2008): "Takeovers," in Handbook of European Financial Markets and Institutions, ed. by P. H. Freixas, X., and C. M. (eds.), pp. 265-297. Oxford University Press.

Cramton, P. (1997): "The FCC spectrum auctions: An early assessment," Journal of Economics and Management Strategy, 6(3), 431-495.

Easley, R. F., And R. Tenorio (2004): "Jump Bidding Strategies in Internet Auctions," Management Science, 50(10), 1407-1419.

Ettinger, D., And F. Michelucci (2015): "Hiding Information in Open Auctions with Jump Bids," The Economic Journal, forthcoming.

Fishman, M. J. (1988): “A Theory of Preemptive Takeover Bidding," The RAND Journal of Economics, 19, 88-101.

Grether, D., D. Porter, And M. Shum (2015): "Cyber-shilling in Automobile Auctions: Evidence from a Field Experiment," American Economic Journal: Microeconomics, fortcoming.

He, Y., and P. Popkowski Leszczyc (2013): "The impact of jump bidding in online auctions," Marketing Letters, pp. 1-11.

Hörner, J., And N. Sahuguet (2007): "Costly Signalling in Auctions," The Review of Economic Studies, 74(1), 173-206.

Krishna, V. (2010): Auction Theory. Academic Press, second edn. 
Mark, I. R., T. C. Salmon, and A. Zillante (2007): "A theory of jump bidding in ascending auctions," Journal of Economic Behavior and Organization., 62(1), 144-164.

Plott, C. R., and T. C. SAlmon (2004): "The simultaneous, ascending auction: dynamics of price adjustment in experiments and in the $\{\mathrm{UK} 3 \mathrm{G}\}$ spectrum auction," Journal of Economic Behavior and Organization, 53(3), 353 - 383. 


\section{Working Paper Series}

ISSN 1211-3298

Registration No. (Ministry of Culture): E 19443

Individual researchers, as well as the on-line and printed versions of the CERGE-EI Working Papers (including their dissemination) were supported from institutional support RVO 67985998 from Economics Institute of the ASCR, v. v. i.

Specific research support and/or other grants the researchers/publications benefited from are acknowledged at the beginning of the Paper.

(c) David Ettinger and Fabio Michelucci, 2015

All rights reserved. No part of this publication may be reproduced, stored in a retrieval system or transmitted in any form or by any means, electronic, mechanical or photocopying, recording, or otherwise without the prior permission of the publisher.

Published by

Charles University in Prague, Center for Economic Research and Graduate Education (CERGE) and

Economics Institute of the ASCR, v. v. i. (EI)

CERGE-El, Politických vězňu 7, 11121 Prague 1, tel.: +420 224005 153, Czech Republic.

Printed by CERGE-EI, Prague

Subscription: CERGE-EI homepage: http://www.cerge-ei.cz

Phone: + 420224005153

Email: office@cerge-ei.cz

Web: http://www.cerge-ei.cz

Editor: Marek Kapička

The paper is available online at http://www.cerge-ei.cz/publications/working_papers/.

ISBN 978-80-7343-342-0 (Univerzita Karlova. Centrum pro ekonomický výzkum a doktorské studium)

ISBN 978-80-7344-334-4 (Akademie věd České republiky. Národohospodářský ústav) 
CERGE-EI

P.O.BOX 882

Politických vězňů 7

11121 Praha 1

Czech Republic http://www.cerge-ei.cz 